\title{
EFEK KOMBINASI PUPUK NITROGEN DAN ZEOLIT TERHADAP PERTUMBUHAN BIBIT BAGAL TEBU (Saccharum officinarum L.)
}

\author{
Darsiman*, Any Kusumastuti, dan Wiwik Indrawati
}

Program Studi Produksi dan Manajemen Industri Perkebunan, Jurusan Budidaya Tanaman Perkebunan Politeknik Negeri Lampung, Jl. Soekarno-Hatta No. 10 Rajabasa, Bandar Lampung, 35144 Telp (0721) 703993 Fax (0721) 78730

*E-mail: darsiman03@gmail.com

\begin{abstract}
ABSTRAK
Tebu (Saccharum officinarum L.) adalah sumber utama produksi gula komersial. Gula adalah komoditas yang sangat penting bagi masyarakat Indonesia baik sebagai kebutuhan dasar maupun bahan baku industri makanan atau minuman. Permintaan gula meningkat dengan pertumbuhan populasi dan beragam makanan. Penelitian ini bertujuan untuk mendapatkan dosis terbaik pupuk Nitrogen dan zeolit untuk mengetahui interaksi antara distribusi pupuk Nitrogen dan zeolit dengan pertumbuhan benih tebu. Penelitian dilakukan di kebun percobaan Politeknik Negeri Lampung, dari Oktober 2018 hingga Maret 2019. Metode yang digunakan adalah Rancangan Acak kelompok (RAK) pola faktorial yang terdiri dari dua faktor perlakuan. Faktor pertama adalah dosis pupuk Nitrogen (Urea) yang terdiri dari tiga taraf, yaitu: N1: 2.1 g.ember $^{-1}$, N2: 3 g.ember $^{-1}$ dan N3: 4 g.ember ${ }^{-1}$. Faktor kedua adalah dosis zeolit yang terdiri dari empat level, yaitu: Z1: 0 g.ember ${ }^{-1}$, N2: 100 g.ember ${ }^{-1}$, N3: 200 g.ember $^{-1}$ dan N4: 300 g. ember ${ }^{-1}$. Hasilnya dianalisis menggunakan analisis varians kemudian dilanjutkan dengan uji perbedaan paling signifikan (LSD) 5\%. Hasil penelitian menunjukkan bahwa dosis pupuk Nitrogen 4 g.ember $^{-1}$ berpengaruh terhadap pertumbuhan bibit bagal tebu pada pengamatan 135 hari setelah tanam yaitu pada variabel diameter batang, jumlah anakan, jumlah ruas, dan bobot kering akar, dosis zeolit tidak berpengaruh terhadap pertumbuhan bibit bagal tebu. Interaksi terjadi pada kombinasi dosis pupuk Nitrogen $\left(4 \mathrm{~g}\right.$.ember $\left.{ }^{-1}\right)$ dan dosis zeolit (100 g. ember $\left.{ }^{-1}\right)$ berpengaruh terhadap pertumbuhan benih tebu hingga diameter batang untuk pengamatan 135 hari setelahtanam.
\end{abstract}

Kata kunci: Tebu, dosis, Urea, Zeolit, interaksi

\section{ABSTRACT}

Sugarcane (Saccharum officinarum L.) is a major source of commercial sugar production. Sugar is a commodity that is essential for the people of Indonesia both as a basic requirement as well as industrial raw material of food or beverage. Sugar demand is increasing with population growth and increasingly diverse array offoods. This study aims to get the best dosage of Nitrogen fertilizer and zeolite to find out the interaction between distribution of Nitrogen fertilizer and zeolite to the growth seeds of sugarcane. Research carried out in the experimental garden of the State Polytechnic of Lampung, from October 2018 to March 2019. The method used was a factorial randomized blok design (RBD) factorial pattern, consisting of two treatment factor. The first factor was a dosage Nitrogen (Urea) fertilizer which consisting of three levels, namely $: N_{1}: 2.1$ 
g.bucket ${ }^{-1}, N_{2}: 3$ g.bucket ${ }^{-1}$ and $N_{3}: 4$ g.bucket ${ }^{-1}$. The second factor wasthe dosage zeolite consisting of four levels, namely: $Z_{1}: 0$ g.bucket ${ }^{-1}, N_{2}: 100$ g.bucket ${ }^{-1}, N_{3}: 200$ g.bucket ${ }^{-1}$ and $N_{4}: 300 \mathrm{~g}$. Bucket ${ }^{-1}$. The result were analyzed using analysis of variance then continued with test least significant diference (LSD) 5\%. The result showed that the dosage Nitrogen fertilizer 4 g.bucket ${ }^{-1}$ take effect to the growth seeds of sugarcane on observation 135 day after planting to rod diameters, amaunt puppis, amaunt segment, and dry roots weights, dosage zeolite no effect to the growth seeds sugarcane. The interaction to combinations dosage Nitrogen fertilizer (4 g.bucket $\left.{ }^{-1}\right)$ and dosage zeolite $\left(100 \mathrm{~g}\right.$. Bucket $\left.{ }^{-1}\right)$ take effect to the growth seeds of sugarcane to roods diameter to observations 135 day afterpalnting.

Keywords: sugarcane, dosage, Urea, Zeolite, Interaction

\section{PENDAHULUAN}

Tebu (Saccharum officinarum L.) merupakan tanaman yang tinggi nilai ekonomisnya, terutama di negara yang beriklim tropis karena terdapat nira pada bagian batangnya yang dapat diolah menjadi gula (Sukmadjaja dan Ade; 2011).

Di Indonesia merupakan salah satu negara strategis untuk perkembangan komoditas tebu karena indonesia memilki iklim tropis sehingga sesuai dengan syarat tumbuh tebu (Artati et al.; 2010) dan (Syakir et al.; 2013) Kondisi tanah yang baik bagi tanaman tebu yaitu tidak terlalu kering dan tidak terlalu basah, selain itu akar tanaman tebu sangat sensitif terhadap kekurangan udara dalam tanah sehingga perairan harus diperhatikan (Indrawanto; 2010).

Produktivitas tebu nasional pada tahun 2017 hanya mencapai $5.453 \mathrm{~kg}$. ha ${ }^{1}$ (Ditjen Perkebunan Mentan RI; 2016) Salah satu faktor penentu dalam produktivitas tanaman tebu adalah penggunaan varietas unggul yang diimplementasikan dalam program penataan varietas berdasarkan kesesuaian topologi lahan, sifat kemasakan, masa tanam, dan masa tebang. Perkebunan tebu dibeberapa negara sudah membangun fasilitas breeding station dalam penyediaan varietas unggul. Beberapa negara sudah menerapkan banyak hal untuk meningkatkan produksi tebu seperti perbaikan sistem tanam, pengairan, pengendalian hama penyakit, dan pemupukan. Tanaman tebu termasuk tanaman yang sangat membutuhkan pupuk untuk dapat menghasilkan tebu dan gula yang lebih baik. Untuk memecahkan masalah ini diperlukan pupuk yang dapat menunjang pertumbuhan tanaman tebu dan kandungan gula didalamnya (Yukamgo et al.;2007)

Pembibitan tebu adalah faktor penentu produksi gula apabila kualitas bibit tebu baik maka akan menentukan keberhasilan budidaya tebu dan menghasilkan rendemen tinggi sehingga produksi gula tinggi. Salah satu faktor yang berpengaruh terhadap hasil pembibitan ialah media tanam. Penggunaan ukuran bibit tebu dapat mempengaruhi pertumbuhan pada pembibitan awal tanaman karena berhubungan dengan kondisi cadangan makanan didalamnya. Semakin besar volume ukuran bibit maka semakin banyak cadangan makanan, sehingga pertumbuhan bibit akan terjamin (Yulianingtyas et al.; 2013).

Disamping itu masalah tanah adalah hal yang penting peningkatan produksi pertanian masih dihadapkan pada rendahnya efisiensi pupuk nitrogen. Sementara itu usaha untuk meningkatkan efisiensi pupuk nitrogen telah banyak dilakukan seperti dengan teknik pemupukan dan membuat pupuk nitrogen dalam bentuk Slow Release Fertilizer (SRF). Namun pupuk SRF yang ada saat ini sebagian besar 
menggunakan bahan kimia yang meninggalkan bahan residu yang dapat merusak tanah. Saat ini orang cenderung menggunakan bahan alam seperti zeolit sebagai bahan SRF didasarkan pada sifat zeolit yang memiliki KTK tinggi dan kemampuan dapat menjerap ion amonium. Dalam prakteknya penggunaan zeolit sebagai bahan SRF dengan mencampur pupuk urea dengan zeolit kemudian dibuat dalam bentuk pil dengan alat granulasi parabola. Tanah yangdihasilkan di daerah tropika basah adalah tanah dengan KTK rendah seperti Oxisol, Ultisol, dan sebagian Inceptisol (Suwardi;2009).

Salah satu alternatif dalam upaya meningkatkan efisiensi pemupukan $\mathrm{N}$ dan mengatasi permasalahan defisiensi $\mathrm{N}$ adalah pemberian bahan pendamping pupuk N. Bahan pendamping pupuk $\mathrm{N}$ yang dapat digunakan adalah zeolit. Zeolit mempunyai muatan negatif yang tinggi sehingga memiliki daya jerap yang kuat dan mampu menyerap ion-ion bermuatan positif dalam tanah seperti ion $\mathrm{H}^{+}$.Ion $\mathrm{H}^{+}$dalam tanah dijerap oleh mineral zeolit dan disimpan dalam rongga-rongga zeolit.Dengan tingginya daya jerap ion $\mathrm{H}^{+}$dalam tanah maka tingkat kemasaman tanah akan berkurang,hal ini dikarenakan ion $\mathrm{H}^{+}$merupakan ion yang mampu menyumbang dan meningkatkan tingkat kemasaman dalam tanah. Dalam hal meningkatkan $\mathrm{pH}$ tanah fungsi zeolit adalah sebagai mineral penjerap ion-ion positif dalam tanah salah satunya adalah ion $\mathrm{H}^{+}$(Bhaskoro dan Kusumarini; 2015).

Kemampuan zeolit sebagai penyerap molekul dan penukar ion dapat digunakan dalam bidang pertanian, antara lain untuk meningkatkan efisiensi pemupukan, meningkatkan KTK tanah, meningkatkan ketersediaan ion $\mathrm{Ca}, \mathrm{K}$, dan $\mathrm{P}$, menurunkan kandungan $\mathrm{Al}$, menahan mineral-mineral yang berguna untuk tanaman, dan menyerap air untuk menjaga kelembaban tanah (Gaol et al.; 2014). Kerusakan tanah perlu segera diperbaiki dengan merubah kebiasaan petani untuk (1) menggunakan pupuk anorganik dan organik secara berimbang, (2) menggunakan pestisida sesuai standar, (3) menggunakan pembenah tanah seperti pupuk organik atau mineral zeolit, dan (4) menggunakan pestisida botanik.Untuk memperbaiki kerusakan fisik dan kImia tanah tersebut dapat menggunakan salah satu pembenah tanah selain berupa pupuk kandang sapijuga dapat menggunakan mineral zeolit (Amin dan Al-Djabri; 2002).

\section{METODE}

Penelitian dilaksanakan di Lahan Pembibitan Tanaman Tebu dan Laboratorium Analisis Kimia Politeknik Negeri Lampung. Penelitian dilakukan pada bulan Oktober 2018 hingga bulan Maret 2019. Bahan yang digunakan dalam penelitian adalah bibit tebu varietas GMP 3, Zeolit $60-80$ mesh, pupuk Urea (N) sebagai perlakuan, sedangkan pupuk SP-36 (P) 200kg.ha-1, $\left(1,2\right.$ g.ember $\left.{ }^{-1}\right)$ dan pupuk $\mathrm{KCl}(\mathrm{K})$ 200kg.ha ${ }^{-1}, \quad\left(1,2\right.$ g.ember $\left.{ }^{-1}\right)$ sebagai pupuk basal, tanah , ember ukuran berat $12 \mathrm{~kg}$ dan bambu. Alat yang digunakan adalah cangkul, golok, ember, ayakan, gembor, meteran, penggaris, jangka sorong, tali rapia, cutter, timbangan (neraca), gergaji, spidol, plastik, label, karung dan alat tulis.

Metode yang digunakan Rancangan Acak Kelompok (RAK) dengan pola faktorial yang terdiri dari dua faktor perlakuan yaitu : Faktor pertama yaitu perlakuan dosis pupuk $\mathrm{N}$ (Urea) yang terdiri dari 3 taraf yaitu: $\mathrm{N}_{1}=$ pupuk $\mathrm{N}$ dosis $350 \mathrm{~kg}$.ha ${ }^{-1}$ setara 2,1 g.ember ${ }^{-1}, \mathrm{~N}_{2}$ $=$ pupuk $\mathrm{N}$ dosis $500 \mathrm{~kg} \cdot \mathrm{ha}^{-1}$ setara 3 g.ember ${ }^{-1}, \mathrm{~N}_{3}=$ pupuk $\mathrm{N}$ dosis 650 kg.ha ${ }^{-1}$ setara 4 g.ember ${ }^{-1}$. Faktor kedua yaitu perlakuan dosis zeolit yang terdiri dari 4 taraf yaitu $: Z_{0}=$ dosis zeolit 0 g.ember ${ }^{-1}, Z_{1}=$ dosis zeolit 16,6 ton.ha ${ }^{-1}$ setara 100 g.ember ${ }^{-1}, Z_{2}=$ dosis zeolit 33,3 ton.ha ${ }^{-1}$ setara 200 g.ember ${ }^{-1}, Z_{3}=$ dosis zeolit 50 ton.ha ${ }^{-1}$ setara 
300g.ember ${ }^{-1}$.

Dari kedua kombinasi pelakuan tersebut antara perlakuan dosis pupuk $\mathrm{N}$ dengan dosis zeolit dilakukan pengulangan sebanyak 3 kali sehingga terdapat 36 satuan percobaan. Setiap satuan percobaan terdiri dari 2 ember. Kombinasi yangdi peroleh sebagai berikut :

$\mathrm{N}_{1} \mathrm{Z}_{0}$ :pupuk $\mathrm{N}$ dosis 2.1 g.ember ${ }^{-1}+$ dosis zeolit 0 g.ember-1

$\mathrm{N}_{1} \mathrm{Z}_{1}$ : pupuk $\mathrm{N}$ dosis 2,1 g.ember ${ }^{-1}+$ dosis zeolit 100 g.ember ${ }^{-1}$

$\mathrm{N}_{1} \mathrm{Z}_{2}$ : pupuk $\mathrm{N}$ dosis 2,1 g.ember ${ }^{-1}+$ dosis zeolit 200 g.ember ${ }^{-1}$

$\mathrm{N}_{1} \mathrm{Z}_{3}$ : pupuk $\mathrm{N}$ dosis 2,1 g.ember ${ }^{-1}+$ dosis zeolit 300 g.ember ${ }^{-1}$

$\mathrm{N}_{2} \mathrm{Z}_{0}$ : pupuk $\mathrm{N}$ dosis 3 g.ember ${ }^{-1}+$ dosis zeolit 0 g.ember ${ }^{-1}$

$\mathrm{N}_{2} \mathrm{Z}_{1}$ : pupuk $\mathrm{N}$ dosis 3 g.ember ${ }^{-1}+$ dosis zeolit 100 g.ember ${ }^{-1}$

$\mathrm{N}_{2} \mathrm{Z}_{2}$ : pupuk $\mathrm{N}$ dosis 3 g.ember ${ }^{-1}+$ dosis zeolit 200 g.ember $^{-1}$

$\mathrm{N}_{2} \mathrm{Z}_{3}$ : pupuk $\mathrm{N}$ dosis 3 g.ember ${ }^{-1}+$ dosis zeolit 300 g.ember ${ }^{-1}$

$\mathrm{N}_{3} \mathrm{Z}_{0}$ : pupuk $\mathrm{N}$ dosis 4 g.ember ${ }^{-1}+$ dosis zeolit 0 g.ember ${ }^{-1}$

$\mathrm{N}_{3} \mathrm{Z}_{1}$ : pupuk $\mathrm{N}$ dosis 4 g.ember ${ }^{-1}+$ dosis zeolit 100 g.ember ${ }^{1}$

$\mathrm{N}_{3} \mathrm{Z}_{2}$ : pupuk $\mathrm{N}$ dosis 4 g.ember ${ }^{-1}+$ dosis zeolit 200 g.ember ${ }^{-1}$

$\mathrm{N}_{3} \mathrm{Z}_{3}$ : pupuk $\mathrm{N}$ dosis 4 g.ember ${ }^{-1}+$ dosis zeolit 300 g.ember ${ }^{-1}$

Untuk mengetahui pengaruh perlakuan pemberian dosis pupuk $\mathrm{N}$ dan Zeolit pada pertumbuhan bibit bagal tebu (bibit berasal dari batang tebu yang diambil sebanyak 2-3 mata tunas batang tebu). Data yang diperoleh dianalaisis ragam, jika hasil uji $\mathrm{F}$ hitung terdapat beda nyata, maka dilanjutkan dengan uji beda nyata terkecil (BNT) pada taraf $5 \%$.

\section{HASIL DAN PEMBAHASAN}

\section{Pengaruh Pemberian Dosis Pupuk N dan Zeolit Terhadap Tinggi Batang}

Berdasarkan hasil sidik ragam variabel tinggi batang terlihat bahwa pemberian dosis pupuk $\mathrm{N}$ dan zeolit menunjukan hasil yang tidak berbeda nyata pada tinggi batang dan tidak terjadi interaksi antara perlakuan dosis pupuk $\mathrm{N}$ dan Zeolit terhadap tinggi batang(Tabel 1).

Tabel 1. Rerata pengaruh pemberian dosis pupuk $\mathrm{N}$ dan zeolit terhadap tinggi batang $(\mathrm{cm})$

\begin{tabular}{|c|c|c|c|c|}
\hline \multirow{2}{*}{ Perlakuan } & \multicolumn{4}{|c|}{ Waktu pengamatan hari setelah tanam(HST) } \\
\hline & $45 \mathrm{HST}$ & $75 \mathrm{HST}$ & $105 \mathrm{HST}$ & $135 \mathrm{HST}$ \\
\hline \multicolumn{5}{|l|}{ Dosis Pupuk N } \\
\hline 2.1 g.ember ${ }^{-1}$ & $18,61 \mathrm{a}$ & $35,50 \mathrm{a}$ & $76,67 \mathrm{a}$ & $120,67 \mathrm{a}$ \\
\hline 3 g.ember ${ }^{-1}$ & $18,06 \mathrm{a}$ & $35,72 \mathrm{a}$ & 80,11 a & $124,77 \mathrm{a}$ \\
\hline 4 g.ember ${ }^{-1}$ & $18,67 \mathrm{a}$ & $35,28 \mathrm{a}$ & $75,11 \mathrm{a}$ & $116,33 \mathrm{a}$ \\
\hline \multicolumn{5}{|l|}{ Dosis Zeolit } \\
\hline 0 g.ember ${ }^{-1}$ & $10,75 \mathrm{a}$ & $20,67 \mathrm{a}$ & $45,25 \mathrm{a}$ & $69,67 \mathrm{a}$ \\
\hline 100 g.ember ${ }^{-1}$ & $9,29 \mathrm{a}$ & $18,83 \mathrm{a}$ & $41,67 \mathrm{a}$ & $68,50 \mathrm{a}$ \\
\hline 200 g.ember ${ }^{-1}$ & $10,54 \mathrm{a}$ & $20,21 \mathrm{a}$ & $44,58 \mathrm{a}$ & $67,83 \mathrm{a}$ \\
\hline 300 g.ember ${ }^{-1}$ & $10,92 \mathrm{a}$ & $20,17 \mathrm{a}$ & $42,42 \mathrm{a}$ & $65,33 \mathrm{a}$ \\
\hline Interaksi & Tidak nyat & $\overline{\text { Tidak nya }}$ & Гidak nya & Tidak nyat \\
\hline
\end{tabular}

Keterangan: Angka rata - rata yang diikuti oleh huruf yang sama menunjukkan tidak berbeda nyata berdasarkan uji BNT taraf 5\%.

Hal ini diduga karena hasil analisis kandungan unsur hara yang terdapat di media tanam berupa unsur hara $\mathrm{N}$ $(0,15 \%), \mathrm{P}(39,8 \mathrm{ppm}), \mathrm{K}(1,13 \%)$, dan
C-organik $(1,14 \%)$ serta $\mathrm{pH}(6,30)$ yang sangat rendah kecuali $\mathrm{P}$. Kandungan unsur hara $\mathrm{N}, \mathrm{P}$ dan $\mathrm{K}$ mempunyai perananan dalam merangsang 
pertumbuhan vegetatif tanaman serta untuk memacu pertumbuhan jaringan terutama pada tinggi tanaman, jumlah anakan, dan panjang daun.

Menurut (Mutryarny et al.; 2014) kandungan unsur hara cukup dan seimbang sangat berguna untuk proses pembelahan, pemanjangan, dan pembesaran sel tanaman.

Hal tersebut mengakibatkan tidak berpengaruh terhadap tinggi batang karena setiap kebutuhan unsur $\mathrm{N}$ yang dibutuhkan tanaman tersedia dalam jumlah yang sama meskipun berasal dari pupuk yang berbeda. Selanjutnya bahwa pemanfaatan pupuk yang diserap oleh akar dapat digunakan oleh tanaman dengan baik untuk membentuk bagianbagian tanaman seperti daun, batang maupun akar mengingat untuk pertumbuhan vegetatif kebutuhan unsur hara $\mathrm{N}, \mathrm{P}$ dan $\mathrm{K}$ dalam jumlah yang berimbang sangat diperlukan oleh tanaman (Anoymaus, 2002) dalam (Suwanan dan Miftakhurrohmat;2014).

\section{Pengaruh Pemberian Dosis Pupuk N dan Zeolit Terhadap Panjang Daun}

Berdasarkan hasil sidik ragam variabel panjang daun terlihat bahwa pemberian dosis pupuk $\mathrm{N}$ dan zeolit menunjukan hasil yang tidak berbeda nyata pada panjang daun dan tidak terjadi interaksi antara perlakuan dosis pupuk $\mathrm{N}$ dan Zeolit terhadap panjang daun (Tabel 2).

Tabel. 2. Rerata pengaruh pemberian dosis pupuk $\mathrm{N}$ dan zeolit terhadap panjang daun $(\mathrm{cm})$

\begin{tabular}{lcccc}
\hline Perlakuan & \multicolumn{4}{c}{ Waktu pengamatan hari setelah tanam(HST) } \\
\cline { 2 - 5 } & $45 \mathrm{HST}$ & $75 \mathrm{HST}$ & $105 \mathrm{HST}$ & $135 \mathrm{HST}$ \\
\hline Dosis Pupuk N & & & & \\
2.1 g.ember $^{-1}$ & $91,94 \mathrm{a}$ & $151,28 \mathrm{a}$ & $189,44 \mathrm{a}$ & $208,22 \mathrm{a}$ \\
3 g.ember $^{-1}$ & $84,17 \mathrm{a}$ & $154,11 \mathrm{a}$ & $192,22 \mathrm{a}$ & $211,78 \mathrm{a}$ \\
4 g.ember $^{-1}$ & $89,78 \mathrm{a}$ & $156,94 \mathrm{a}$ & $192,11 \mathrm{a}$ & $211,11 \mathrm{a}$ \\
\hline Dosis Zeolit & & & & \\
0 g.ember & & & & \\
100 g.ember $^{-1}$ & $51,96 \mathrm{a}$ & $87,46 \mathrm{a}$ & $107,00 \mathrm{a}$ & $118,25 \mathrm{a}$ \\
200 g.ember $^{-1}$ & $46,63 \mathrm{a}$ & $84,79 \mathrm{a}$ & $108,92 \mathrm{a}$ & $119,25 \mathrm{a}$ \\
300 g.ember & $49,83 \mathrm{a}$ & $88,58 \mathrm{a}$ & $107,58 \mathrm{a}$ & $118,50 \mathrm{a}$ \\
Interaksi & $51,00 \mathrm{a}$ & $85,92 \mathrm{a}$ & $106,83 \mathrm{a}$ & $117,33 \mathrm{a}$ \\
\hline
\end{tabular}

Keterangan: Angka rata - rata yang diikuti oleh huruf yang sama menunjukkan tidak berbeda nyata berdasarkan uji BNT taraf $5 \%$.

Pemberian dosis pupuk $\mathrm{N}$ tidak berpengaruh terhadap panjang daun tanaman tebu.Hal ini diduga karena penggunaan dosis pupuk $\mathrm{N}$ yang rendah dapat menyebabkan pertumbuhan, perkembangan sel dan pemanjangan daun terganggu karena unsur hara $\mathrm{N}$ tidak terabsorpsi secara maksimal oleh tanaman. Menurut (Mutryarny et al.; 2014) proses pembelahan, pemanjangan, dan pembesaran sel berlangsung dengan cepat sehingga beberapa organ tanaman tumbuh dengan cepat pula, hal ini dapat terjadi apabila pada saat pertumbuhan tanaman kandungan unsur hara cukup dan seimbang. Dugaan yang lain karena fungsi zeolit yang dapat mengikat unsur hara dan melepaskannya kembali secara perlahan lahan sesuai yang dibutuhkan tanaman sehingga cenderung dalam kurun waktu yang lama, pada tanaman tebu yang berumur 135 HST belum terlihat pengaruhnya terhadap pertumbuhan tinggi batang tebu, sesuai dengan pernyataan (M. Al-jabri R dan Soegianto. R; 2014) bahwa residu zeolit 
dalam tanah masih bertahan dalam waktu yang cukup lama, sebab zeolit tidak mengalami break down sehingga jumlahnya masih tetap dalam tanah. Hal ini diduga karena tanaman tebu dapat mengabsorpsi unsur hara Nitrogen yang terdapat pada pupuk dengan cepat sehingga pengaruh pemberian pupuk $\mathrm{N}$ terhadap tanaman dapat langsung terlihat. Hal ini berbeda dengan zeolit yang dapat mengikat unsur hara dan melepaskanya kembali secara perlahan sesuai dengan kebutuhan tanaman sehingga cenderung dalam kurun waktu yang lama.

\section{Pengaruh Pemberian Dosis Pupuk N dan Zeolit Terhadap Diameter Batang}

Berdasarkan hasil sidik ragam variabel diameter batang terlihat bahwa pemberian dosis pupuk $\mathrm{N}$ berbeda nyata dan zeolit menunjukan hasil yang tidak berbeda nyata pada diameter batang serta terjadi interaksi antara perlakuan dosis pupuk $\mathrm{N}$ dan Zeolit terhadap diamter batang (Tabel 3).

Tabel 3. Rerata pengaruh pemberian dosis pupuk $\mathrm{N}$ dan zeolit terhadap diameter batang $(\mathrm{cm})$

\begin{tabular}{|c|c|c|c|c|c|}
\hline \multirow{2}{*}{ Perlakuan } & & \multicolumn{4}{|c|}{ Waktu pengamatan hari setelah tanam(HST) } \\
\hline & & $45 \mathrm{HST}$ & 75 HST & 105 HST & 135 HST \\
\hline \multicolumn{6}{|l|}{ Dosis Pupuk N } \\
\hline \multicolumn{2}{|l|}{2.1 g.ember ${ }^{-1}$} & $0,93 \mathrm{a}$ & $1,73 \mathrm{a}$ & $3,09 \mathrm{~b}$ & $3,45 \mathrm{~b}$ \\
\hline \multicolumn{2}{|l|}{3 g.ember ${ }^{-1}$} & $0,92 \mathrm{a}$ & $1,61 \mathrm{a}$ & $3,09 \mathrm{~b}$ & $3,43 \mathrm{~b}$ \\
\hline \multicolumn{2}{|l|}{4 g.ember ${ }^{-1}$} & $0,93 \mathrm{a}$ & $1,66 \mathrm{a}$ & $3,27 \mathrm{a}$ & $3,54 \mathrm{a}$ \\
\hline \multicolumn{6}{|l|}{ Dosis Zeolit } \\
\hline \multicolumn{2}{|l|}{0 g.ember ${ }^{-1}$} & $0,53 \mathrm{a}$ & $0,94 \mathrm{a}$ & $1,77 \mathrm{a}$ & $1,93 \mathrm{a}$ \\
\hline \multicolumn{2}{|l|}{100 g.ember ${ }^{-1}$} & $0,47 \mathrm{a}$ & $0,89 \mathrm{a}$ & $1,79 \mathrm{a}$ & $1,99 \mathrm{a}$ \\
\hline \multicolumn{2}{|l|}{200 g.ember ${ }^{-1}$} & $0,55 \mathrm{a}$ & $0,97 \mathrm{a}$ & $1,78 \mathrm{a}$ & $1,96 \mathrm{a}$ \\
\hline \multicolumn{2}{|l|}{300 g.ember ${ }^{-1}$} & $0,53 \mathrm{a}$ & $0,95 \mathrm{a}$ & $1,76 \mathrm{a}$ & $1,94 \mathrm{a}$ \\
\hline \multicolumn{6}{|l|}{ Interaksi } \\
\hline \multirow[t]{4}{*}{2.1 g.ember $^{-1}$} & 0 g.ember ${ }^{-1}$ & $0,75 \mathrm{a}$ & $1,43 \mathrm{a}$ & $2,45 \mathrm{a}$ & $2,65 \mathrm{a}$ \\
\hline & 100 g.ember ${ }^{-1}$ & $0,62 \mathrm{a}$ & $1,13 \mathrm{a}$ & $2,24 \mathrm{a}$ & $2,57 \mathrm{~b}$ \\
\hline & 200 g.ember $^{-1}$ & $0,76 \mathrm{a}$ & $1,37 \mathrm{a}$ & $2,29 \mathrm{a}$ & $2,56 \mathrm{~b}$ \\
\hline & 300 g.ember ${ }^{-1}$ & $0,66 \mathrm{a}$ & $1,26 \mathrm{a}$ & $2,31 \mathrm{a}$ & $2,56 \mathrm{~b}$ \\
\hline \multirow[t]{4}{*}{3 g.ember ${ }^{-1}$} & 0 g.ember ${ }^{-1}$ & $0,68 \mathrm{a}$ & $1,12 \mathrm{a}$ & $2,24 \mathrm{a}$ & $2,49 \mathrm{~b}$ \\
\hline & 100 g.ember ${ }^{-1}$ & $0,60 \mathrm{a}$ & $1,20 \mathrm{a}$ & $2,32 \mathrm{a}$ & $2,63 \mathrm{~b}$ \\
\hline & 200 g.ember ${ }^{-1}$ & $0,79 \mathrm{a}$ & $1,28 \mathrm{a}$ & $2,42 \mathrm{a}$ & $2,62 \mathrm{~b}$ \\
\hline & 300 g.ember ${ }^{-1}$ & $0,68 \mathrm{a}$ & $1,23 \mathrm{a}$ & $2,29 \mathrm{a}$ & $2,56 \mathrm{~b}$ \\
\hline \multirow[t]{4}{*}{4 g.ember ${ }^{-1}$} & 0 g.ember ${ }^{-1}$ & $0,70 \mathrm{a}$ & $1,20 \mathrm{a}$ & $2,39 \mathrm{a}$ & $2,57 \mathrm{~b}$ \\
\hline & 100 g.ember ${ }^{-1}$ & $0,67 \mathrm{a}$ & $1,22 \mathrm{a}$ & $2,60 \mathrm{a}$ & $2,76 \mathrm{a}$ \\
\hline & 200 g.ember ${ }^{-1}$ & $0,63 \mathrm{a}$ & $1,23 \mathrm{a}$ & $2,39 \mathrm{a}$ & $2,65 \mathrm{a}$ \\
\hline & 300 g.ember ${ }^{-1}$ & $0,78 \mathrm{a}$ & $1,31 \mathrm{a}$ & $2,44 \mathrm{a}$ & $2,64 \mathrm{~b}$ \\
\hline
\end{tabular}

Keterangan: Angka rata - rata yang diikuti oleh huruf yang sama menunjukkan tidak berbeda nyata berdasarkan uji BNT taraf 5\%.

Tabel 3, menunjukkan bahwa pemberian dosis pupuk $\mathrm{N}$ pada pengamatan 45 dan 75 HST tidak berbeda nyata terhadap diameter batang tanaman tebu tetapi, pada pengamatan 105 dan 135 HST memberikan pengaruh terhadap diameter batang tanaman tebu. $\mathrm{Hal}$ ini diduga karena pada pengamatan 45 dan 75 HST, tanaman sedang dalam proses pertumbuhan sehingga pemberian dosis pupuk $\mathrm{N}$ pada tanaman tebu tidak memberikan pengaruh pada diameter batang, pada pengamatan 105 dan 135 HST memberikan pengaruh terhadap diameter batang tebu hal ini karena pemberian dosis pupuk $\mathrm{N}$ yang semakin tinggi diharapkan dapat meningkatkan 
unsur hara $\mathrm{N}$ didalam tanah yang dapat di manfaatkan tanaman untuk membentuk pertumbuhan batang, penggunaan pupuk yang efektif dan seimbang diharapkan dapat meningkatkan kesuburan tanaman. Menurut (Soomroa et al.; 2014) ketersediaan hara $\mathrm{N}$, $\mathrm{P}$, dan $\mathrm{K}$ yang tinggi dalam jaringan tanaman menyebabkan pertumbuhan batang lebih cepat.

Tabel 3 menunjukkan bahwa pemberian dosis pupuk $\mathrm{N}$ dan zeolit memberikan interaksi terhadap diameter batang tebu. Hal ini diduga karena Zeolit yang dicampur dengan pupuk urea mengikat ion amonium yang dilepaskan pupuk urea pada saat penguraian. Rongga zeolit yang berukuran 2-8 Angtrom sesuai dengan ukuran ion amonium. Pengikatan akan lebih efektif jika jumlah zeolit yang dicampurkan ke dalam pupuk urea semakin banyak, karena kompleks jerapan dan rongga yang dapat menangkap ion amonium semakin banyak. Ion amonium yang dijerap zeolit tidak segera dilepas ke dalam larutan tanah selama jumlah ion amonium dalam tanah masih tinggi (Suwardi;2009).

\section{Pengaruh Pemberian Dosis Pupuk N dan Zeolit Terhadap Jumlah Anakan Tebu}

Berdasarkan hasil sidik ragam variabel jumlah anakan terlihat bahwa pemberian pupuk $\mathrm{N}$ berpengaruh terhadap jumlah anakan, akan tetapi pada perlakuan pemberian dosis Zeolit serta interaksi antara pemberian dosis pupuk $\mathrm{N}$ dan Zeolit tidak berpengaruh nyata terhadap jumlah anakan. Uji BNT taraf 5\% dapat diketahui bahwa pemberian pupuk $\mathrm{N}$ berpengaruh nyata terhadap jumlah anakan (Tabel 4).

Pemberian dosis pupuk $\mathrm{N}$ tidak berbeda nyata terhadap jumlah anakan tanaman tebu.Hal ini diduga karena kandugan unsur hara yang ada di media tanam sangat rendah dan pada saat pemberian dosis pupuk $\mathrm{N}$ pada media tanam kandungan unsur hara $\mathrm{N}$ yang ada di media tanam masih belum cukup untuk diabsorbsi oleh tanaman, kekurangan unsur hara $\mathrm{N}$ mengakibatkan pembentukan anakan tanaman tebu menjadi rendah dan jika kandungan unsur hara $\mathrm{N}$ yang berada di media tanam terpenuhi maka proses pembentukan anakan menjadi lebih banyak. Hal ini didukung oleh (Permana et al.; 2015) mengemukakan bahwa semakin banyak kandungan unsur hara $\mathrm{N}$, maka jumlah anakan yang terbentuk semakinbanyak.

Tabel. 4. Rerata pengaruh pemberian dosis pupuk $\mathrm{N}$ dan zeolit terhadap jumlah anakan

\begin{tabular}{cc}
\hline \multirow{2}{*}{ Perlakuan $\begin{array}{c}\text { Waktu pengamatan hari } \\
\text { setelah tanam(HST) }\end{array}$} \\
\cline { 2 - 3 } & 45 HST75 HST135 HST \\
\hline
\end{tabular}

Dosis Pupuk N

2.1 g.ember ${ }^{-1} \quad 6,55$ a 6,67 a 6,78 b

3 g.ember ${ }^{-1} \quad 7,44$ a 7,44 a 7,78 a

4 g.ember $^{-1} \quad 8,00$ a 7,78 a 8,22 a

Dosis Zeolit

0 g.ember ${ }^{-1} \quad 3,92$ a $\quad 4,00$ a 4,50 a

100 g.ember ${ }^{-1} 4,08$ a 4,00 a 4,08 a

200 g.ember ${ }^{-1} 4,17$ a 4,08 a 4,00 a

300 g.ember ${ }^{-1} \quad 4,33$ a 4,33 a 4,50 a

Interaksi Tidak Tidak Tidak nyata nyata nyata

Keterangan: Angka rata - rata yang diikuti oleh huruf yang sama menunjukkan tidak berbeda nyata berdasarkan uji BNT taraf $5 \%$.

\section{Pengaruh Pemberian Dosis Pupuk N dan Zeolit Terhadap Jumlah Ruas Tebu}

Berdasarkan hasil sidik ragam variabel jumlah anakan terlihat bahwa pemberian pupuk $\mathrm{N}$ berpengaruh terhadap jumlah ruas, akan tetapi pada perlakuan pemberian dosis Zeolit serta interaksi antara pemberian dosis pupuk $\mathrm{N}$ dan Zeolit tidak berpengaruh nyata 
terhadap jumlah ruas. Uji BNT taraf 5\% dapat diketahui bahwa pemberian dosis pupuk $\mathrm{N}$ berpengaruh nyata terhadap jumlah ruas (Tabel.5).

Tabel 5. Rerata pengaruh pemberian dosis pupuk $\mathrm{N}$ dan zeolit terhadap jumlah ruas

\begin{tabular}{cc}
\hline Perlakuan & $\begin{array}{c}\text { Waktu pengamatan hari } \\
\text { setelah tanam(HST) } \\
\text { 45 HST75 HST 105 HST }\end{array}$ \\
\hline
\end{tabular}

Dosis pupuk tuggal $\mathrm{N}$

\begin{tabular}{|c|c|c|c|}
\hline $\mathrm{er}^{-1}$ & $2,56 \mathrm{a}$ & $5,11 \mathrm{a}$ & \\
\hline 3 g.ember ${ }^{-1}$ & $11 \mathrm{a}$ & 5,5 & $33 \mathrm{~b}$ \\
\hline 4 g.er & & & \\
\hline \multicolumn{4}{|l|}{ Dosis Zeolit } \\
\hline & $1,67 \mathrm{a}$ & $3,1^{\prime}$ & 3,58 \\
\hline $00 \mathrm{~g}$. & 1,5 & 3,0 & 3,15 \\
\hline $00 \mathrm{~g}$ & 1,58 & 3,3 & 3,75 \\
\hline 300 g.embe & $1,83 \mathrm{a}$ & $3,00 \mathrm{a}$ & $3,67 \mathrm{a}$ \\
\hline 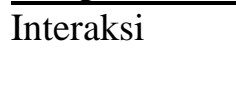 & & & \\
\hline
\end{tabular}

Keterangan: Angka rata - rata yang diikuti oleh huruf yang sama menunjukkan tidak berbeda nyata berdasarkan uji BNT taraf $5 \%$.

Tabel 5 menunjukkan bahwa pada pengamatan 105 dan 120 HST pemberian dosis pupuk $\mathrm{N}$ tidak berpengaruh terhadap jumlah anakan tanaman tebu. Hal ini diduga karena kekurang unsur hara $\mathrm{N}$ yang terdapat di media tanam dan juga dosis pupuk $\mathrm{N}$ yang diberikan belum cukup bagi tanaman sehingga kandungan unsur hara $\mathrm{N}$ yang sangat penting berfungsi untuk membantu proses pertambahan dan pertumbuhan batang menjadi teranggu. (Sumanto; 2016) mengatakan bahwa kebutuhan $\mathrm{N}$ untuk tanaman merupakan unsur utama, disamping unsur lain yang sangat dibutuhkan tebu yang mempengaruhi hasil dan kualitas tebu, terutama fase vegetatif yaitu untuk pembentukan tunas, pembentukan daun, pertumbuhan batang, dan akar.

Pemberian pupuk $\mathrm{N}$ pada pengamatan 135 HST berpengaruh terhadap jumlah ruas tanaman tebu. Hal ini dikarenakan pemberian pupuk $\mathrm{N}$ dalam jumlah yang cukup optimal dapat membantu pertumbuhan tanaman tebu terutama dalam proses pembesaran dan pembentukan batang pengguna dosis pupuk yang semakin tinggi diharapkan dapat dimanfaatkan tanaman tebu secara efektif dalam pertumbuhan dan pembentukan ruas batang tebu. Halini sesuai dengan pernyataan (Prayogo dan Amir; 2016) bahwa untuk menghasilkan pertumbuhan yang optimal tanaman tebu membutuhkan masukan pupuk yang cukup tinggi sehingga kandungan unsur hara dapat terpenuhi dan produksinya menjadi optimal.

Bila dosis pupuk terlalu rendah, tidak ada pengaruhnya terhadap pertumbuhan tanaman, sedangkan bila dosis terlalu banyak dapat mengganggu setimbangan hara dan dapat meracuni akar tanaman.

\section{Pengaruh Pemberian Dosis Pupuk N dan Zeolit Terhadap Berat Akar Tebu}

Berdasarkan hasil sidik ragam variabel berat kering akar terlihat bahwa pemberian pupuk $\mathrm{N}$ berpengaruh terhadap berat kering akar, akan tetapi pada perlakuan pemberian dosis Zeolit serta interaksi antara pemberian dosis pupuk $\mathrm{N}$ dan Zeolit tidak berpengaruh nyata terhadap berat kering akar. Uji BNT taraf 5\% dapat diketahui bahwa pemberian dosis pupuk $\mathrm{N}$ berpengaruh nyata terhadap berat kering akar (Tabel.6).

Tabel 6, menunjukkan bahwa pemberian pupuk $\mathrm{N}$ pada pengamatan 135 HST berpengaruh terhadap bobot kering akar tanaman tebu. Hal ini dikarenakan bahwa pada perlakuan pemberian dosis pupuk tunggal $\mathrm{N}$ berpengaruh terhadap bobot kering akar tanaman tebu. Perlakuan pemberian dosis 4 g.ember ${ }^{-1}$ menunjukkan rerata bobot kering akar tebu tertinggi yaitu (61,91 gram), kemudian diikuti dengan dosis 3 g.ember ${ }^{-1}$ yaitu $(46,24$ gram) 
sedangkan bobot kering akar tebu terendah terjadi pada perlakuan pemberian dosis 2.1 g.ember ${ }^{-1}$ yaitu (41,93 gram). Hal ini diduga karena pada perlakuan pemberian dosis pupuk $\mathrm{N} 4$ g.ember ${ }^{-1}$ menunjukan berat kering akar tertinggi disebabkan semakin tinggi pemberian dosis pupuk diharapkan tanaman dapat tumbuh semakin subur sehingga pertumbuhan akarnya juga semakin tinggi. Hal ini juga diungkapkan oleh (Larcher, 1975) dalam (Nisa; 2018) berat kering tanaman merupakan hasil penimbunan hasil bersih asimilasi $\mathrm{CO}_{2}$ yang dilakukan selama pertumbuhan dan perkembangan tanaman. Pertumbuhan itu sendiri dapat dianggap sebagai suatu peningkatan berat basah dan penimpunan bahan kering. Jadi, semakin baik pertumbuhan tanaman maka berat kering juga semakin meningkat.

Tabel. 6. Rerata pengaruh pemberian dosis pupuk $\mathrm{N}$ dan zeolit terhadap bobot kering akar (g)

\begin{tabular}{|c|c|}
\hline$\overline{\text { Perlakuan }}$ & $\begin{array}{c}\text { Rerata bobot kering akar } \\
(\mathrm{g})\end{array}$ \\
\hline \multicolumn{2}{|c|}{ Dosis pupuk tuggal $\mathrm{N}$} \\
\hline 2.1 g.ember ${ }^{-1}$ & $41,93 \mathrm{~b}$ \\
\hline 3 g.ember $^{-1}$ & $46,24 \mathrm{~b}$ \\
\hline 4 g.ember ${ }^{-1}$ & $61,91 \mathrm{a}$ \\
\hline \multicolumn{2}{|l|}{ Dosis Zeolit } \\
\hline 0 g.ember ${ }^{-1}$ & $25,78 \mathrm{a}$ \\
\hline 100 g.ember ${ }^{-1}$ & $27,05 \mathrm{a}$ \\
\hline 200 g.ember $^{-1}$ & $26,94 \mathrm{a}$ \\
\hline 300 g.ember ${ }^{-1}$ & $32,80 \mathrm{a}$ \\
\hline Interaksi & Tidak nyata \\
\hline
\end{tabular}

Keterangan: Angka rata - rata yang diikuti oleh huruf yang sama menunjukkan tidak berbeda nyata berdasarkan uji BNT taraf $5 \%$.

\section{SIMPULAN}

Dosis pupuk $\mathrm{N}$ berpengaruh terhadap pertumbuhan bibit bagal tebu (Saccharum Officinarum L) pada pengamatan 135 HST terhadap diameter batang, jumlah anakan,jumlah ruas dan bobot kering akar. Dosis zeolit tidak berpengaruh terhadap semua variabel pengamatan pertumbuhan bibit bagal tebu (Saccharum Officinarum L). Interaksi antara pemberian dosis pupuk N (4 g.ember $\left.{ }^{-1}\right)$ dan dosis Zeolit (100 g.ember $\left.{ }^{-1}\right)$ mempengaruhi pertumbuhan bibit bagal tebu (Saccharum Officinarum $L$ ) terhadap diameter batang pada pengamatan $135 \mathrm{HST}$.

\section{SARAN}

Perlu dilakukan penelitian lebih lanjut dengan menggunakan dosis pupuk $\mathrm{N}$ dan zeolit yang lebih tinggi yang dilaksanakan dengan waktu yang lebih lama (penelitian dilakukan sampai panen) untuk mengetahui pengaruh dosis pupuk $\mathrm{N}$ danZeolit.

\section{UCAPAN TERIMA KASIH}

Penulis mengucapkan terima kasih terkhusus kepada Dosen Pembimbing dalam penyusunan dan terimakasih juga kepada seluruh Dosen Jurusan Budidaya Tanaman Perkebunan Politeknik Negeri Lampung yang telah membantu dan memberikan saran dalam penelitian ini

\section{DAFTAR PUSTAKA}

Amin, M., dan Al-Djabri, M. 2002. Pengaruh Pemberian Zeolit dan Pupuk Kandang Sapi Terhadap Pertumbuhan dan Hasil Bawang Merah di Kabupaten Brebes :1979.

Artati, E.K., E, Margareta., dan H, V.Widhie. 2010. Konstanta Kecepatan Reaksi Sebagai Fungsi Suhu pada Hidrolisa Selulosa dari Ampas Tebu dengan Katalisator Asam Sulfat. Ekuilibrium. 9:1, 1-4.

Bhaskoro, A.W., dan Kusumarini, N. 2015. Efisiensi Pemupukan Nitrogen Tanaman Sawi pada Inceptisol Melalui Aplikasi Zeolit Alam. Malang 2:2, 219-226.

Ditjen Perkebunan Mentan RI. 2016. Statistik Perkebunan Tebu 20152017, Dr. Ir. De. ed. Sekretariat Direktorat Jenderal Perkebunan. 
Jakarta.

Gaol, S.K.L., Hanum, H., dan Sitanggang, G. 2014. Pemberian Zeolit dan Pupuk Kalium Untuk Meningkatkan Ketersediaan Hara

Darsiman., A. Kusumastuti and W. Indrawati. 2019. Efek Kombinasi Pupuk Nitrogen dan Zeolit Terhadap Pertumbuhan Bibit Bagal Tebu (Saccharum officinarum L.).11511159.

Indrawanto, C. 2010. Budidaya dan Pasca Panen TEBUESKA media. Bogor. 13:8, 15-20.

M. Al-jabri R, dan Soegianto. R. 2014. Teknologi Zeolite untuk Pengembangan Pertanian yang Sangat Menjanjikan Zeolite Technology for Agriculture Development is Very .Brebes :500508.

Mutryarny, E., Endriani, and S, U, L. 2014. Pemanfaatan Urine Kelinci untuk Meningkatkan Pertumbuhan dan Produksi Tanaman Sawi (Brassica juncea L) Varietas Tosakan 11:2, 23-34. Pekanbaru.

Nisa, C. 2018. Pengaruh Berbagai Macam Kotoran Ikan Terhadap Pertumbuhan dan Produksi Tanaman Selada ( Lactuca sativa L.) pada Sistem Akuaponik. Medan

Permana, A.D., Baskara, M., and Eko Widaryanto. 2015. Pengaruh Perbedaan Umur Bibit Single Bud Planting dengan Pemupukan Nitrogen pada Pertumbuhan Awal Tanaman Tebu (Saccharum officinarum L.) J. Produksi Tanam. 3, 424 - 432. Malang.

Prayogo, S.A., dan Amir, N. 2016. Pengaruh Jenis Pupuk Organik dan Sistem Tanam Terhadap Pertumbuhan Bibit Tanaman Tebu (Saccharum officinarum L.) 51-55.
Palembang.

Soomroa, A.F., Tunio, S., Keerio, M.I., and Inaitullah Rajper. 2014. Effect of inorganic NPK fertilizers under different proportions on growth, yield and juice quality of sugarcane (Saccharum officinarum L). Abdul Fatah Soomro. Pakistan. 3:1, 10-18. Sukmadjaja, D., dan Ade, M. 2011. Regenerasi dan Pertumbuhan Beberapa Varietas Tebu ( Saccharum officinarum $L$.) secara In Vitro. Banten. 7:2, 106-118.

Sumanto. 2016. The Production of Tissue Culture Cane Seed G3 PS862 Variety on Plant Spacing and Cow Manure Application. Bogor 22:2, 99106.

Suwanan, dan Miftakhurrohmat, A. 2014. Pengaruh Kombinasi Pupuk Anorganik dan Jumlah Mata Tunas Terhadap Pertumbuhan Awal Tanaman Tebu (Saccharum officinarum L.). Nabatia. Sidoarjo. 11:1.

Suwardi. 2009. Teknik Aplikasi Zeolit di Bidan Pertanian Sebagai Bahan Pembenah Tanah. Jurnal Zeolit Indonesia. 8, 33-38.Bogor.

Syakir, M., Sutopo, D., and Damanik,

S. 2013. Analisa Usahatani Budi Daya Tebu Intensif, Studi Kasus di Kabupaten Purbalingga Bul. Tanam. Tembakau, Serat Minyak Industri 5:2, 51-57. Bogor.

Yukamgo, E., dan Yuwono, W. 2007. Peran Silikon Sebagai Unsur Bermanfaat Pada Tanaman Tebu 7:2, 103-116. Yogyakarta.

Yulianingtyas, A.P., Sebayang, H.T., and Tyasmoro, S.Y. 2013. Pengaruh Komposisi Media Tanam dan Ukuran Bibit Pada Pertumbuhan Pembibitan Tebu (Saccharum officinarum L.). J. Produksi Tanam.Malang. 